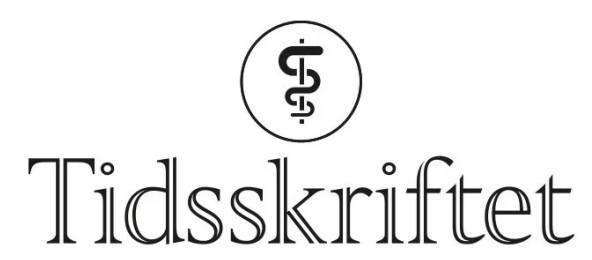

DEN NORSKE LEGEFORENING

\title{
Skolestengning og/eller sosial distansering?
}

FRA ANDRE TIDSSKRIFTER

LISE SKOGSTAD LOFTSGAARD

Tidsskriftet

Begrenset sosial kontakt i befolkningen er et mer effektivt smitteverntiltak enn skolestengning, ifølge en amerikansk studie.

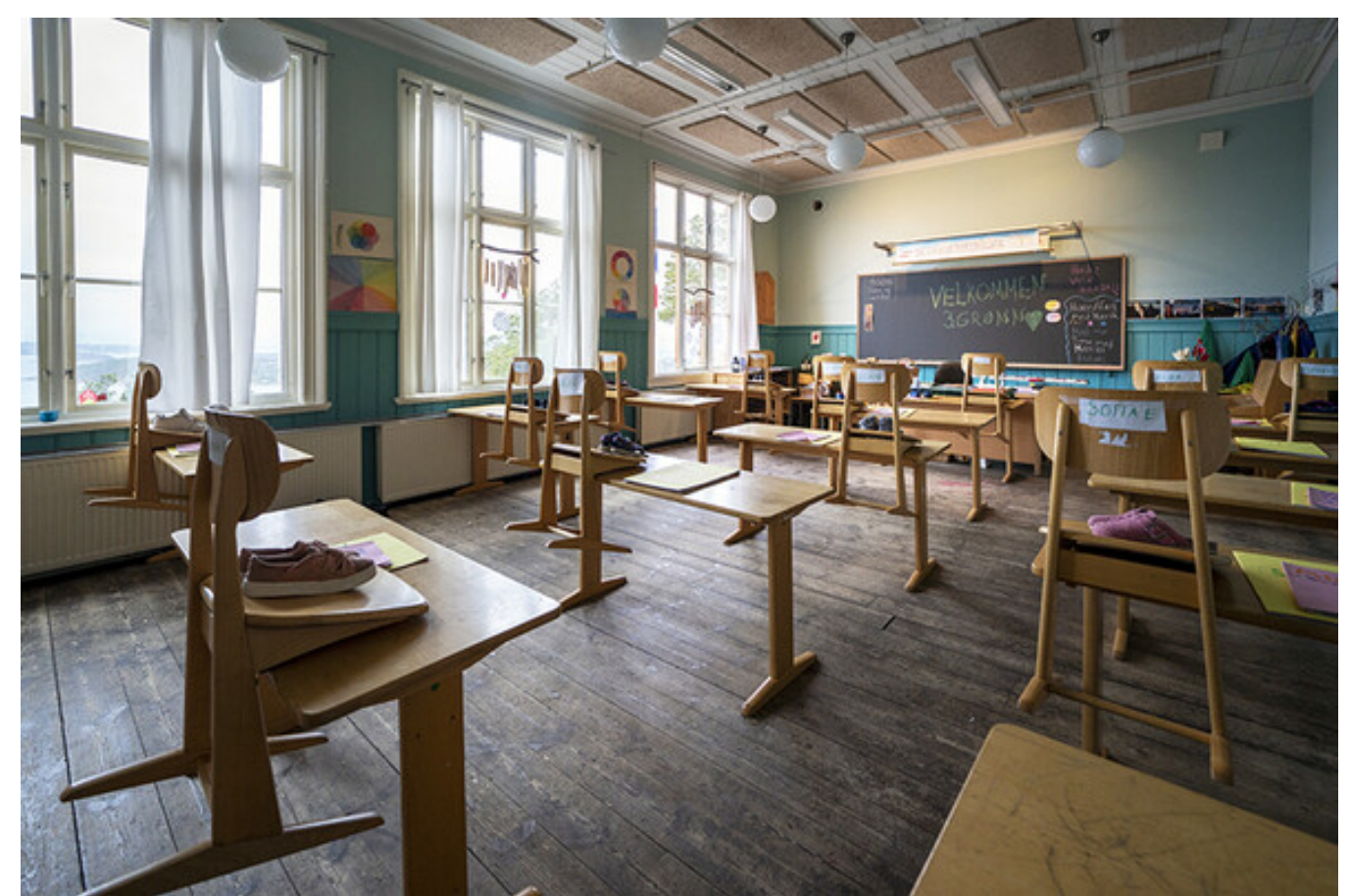

3. klasse-rommet på Nordstrand Steinerskole da skolene åpnet igjen 27. april 2020. Foto: Heiko Junge / NTB

Skolestengning for å hindre spredning av viruset som forårsaker covid-19, er omdiskutert. Hvor godt virker det egentlig?

I en populasjonsstudie i USA ble forekomst og dødelighet av covid-19 registrert i en 60 dagers periode fra mars til mai 2020 (1). Data om befolkningens atferd var basert på bruk av mobiltelefon og internett i samme periode og ble sammenliknet med perioden fra 
januar til februar samme år. Tidspunkt for stengning av spisesteder og skoler i ulike delstater ble registrert.

I løpet av studieperioden endret befolkningen atferd: Antall restaurantbesøk og tid på arbeidsplassen sank med hhv. $98 \%$ og $40 \%$, mens tid i hjemmet $\varnothing$ kte med ca. $15 \%$. I justerte analysemodeller hadde slike atferdsendringer en langt større effekt på insidensen av covid19 enn skolestengninger. Simuleringer tydet på at to ukers utsettelse av skolestengning ville gitt rundt 23 ooo flere dødsfall ( $95 \%$ KI 2 ooo-62 ooo), mens to ukers utsettelse av atferdsendringer og uendret skolestengning ville gitt rundt 140 ooo flere dødsfall ( $95 \% \mathrm{KI}$ 65 000-294 000).

- Styrken ved denne studien er at den beregner effekter av ulike smitteverntiltak samtidig, sier Pål Surén, som er barnelege, epidemiolog og forsker ved Folkehelseinstituttet. Studien viser at den smittereduserende effekten av skolestengning er langt mindre enn effekten av andre kontaktreduserende tiltak. Dette skyldes antagelig at barn er mindre mottagelige for SARS-CoV-2, og at de har lavere tilbøyelighet til å smitte videre, sier Surén.

- I Norge ser vi at stengning av skoler i juleferien og vinterferien ikke hadde noen bremsende effekt på smitte blant barn og ungdom. Sannsynligvis skyldes dette mer sosialt samvær og generell tiltakstretthet, mener Surén. Hvis skolestengning skal ha effekt, må de nok gjennomføres under samme betingelser som i studien fra USA, dvs. i kombinasjon med andre kontaktreduserende tiltak og med god etterlevelse i befolkningen. Den smittereduserende effekten av skolestengning ser ut til å være liten i forhold til tiltakets store kostnader. Derfor bør nok andre smitteverntiltak prioriteres, sier Surén.

\section{LITTERATUR}

1. Zimmerman FJ, Anderson NW. Association of the timing of school closings and behavioral changes with the evolution of the coronavirus disease 2019 pandemic in the US. JAMA Pediatr 2021; 175. doi: 10.1001/jamapediatrics.2020.6371. [PubMed][CrossRef]

Publisert: 21. april 2021. Tidsskr Nor Legeforen. DOI: 10.4045/tidsskr.21.0237

(C) Tidsskrift for Den norske legeforening 2023. Lastet ned fra tidsskriftet.no 26. april 2023. 